\title{
論 文 $16-3-4$
}

\section{공간벡터 $\mathrm{PWM}$ 을 이용한 간단한 정적 과변조기법}

\author{
李東明*, 金填鎬" ${ }^{* *}$ 梁玄錫 ${ }^{* * *}$, 鄭鎭佑 $^{\dagger}$
}

\section{A Simple Static Overmodulation Scheme using Space Vector PWM Method}

\author{
Dong-Myung Lee, Jin-Ho Kim, Hyun-Suk Yang, and Jin-Woo Jung
}

요 약

본 논문은 출력 전압의 선형성을 확장하기위한 정적 과변조 기법에 대한 것이다. 제안하는 방식은 기본파 전압 크기 지령에 해당하는 변조 지수로부터 직접 과변조 영역에서의 순시치 전압 크기를 얻어내는 방식을 취하며, 전압 위상 지령의 형태도 간소화시킨 간단한 정적 과변조 기법이다. 제안된 기법은 지령치 전압 크기 계산시 삼각함수의 연산이 불필요하다. 순시치 전압 크기와 유지각은 출력전압의 크기가 변조 지수에 해당하는 지령치 전압의 기본파 크기와 동일하도록 푸리에 급수 전개를 통하여 미리 계산된 근사식을 이용한다.

\section{ABSTRACT}

This paper proposes a simple static overmodulation strategy that extends the linearity of the inverter output voltage. The proposed method obtains the reference vector having the instantaneous value directly from the modulation index based on the magnitude of fundamental voltage, and has a simplified form of phase command. This method does not need trigonometric functions for calculating the magnitude of the reference vector. The magnitude of reference voltage and holding angle in the overmodulation region corresponding to the modulation index are determined in advance to have the same fundamental voltage magnitude by using the result of Fourier series expansion.

Key Words : SVPWM(Space Vector PWM), Overmodulation, Fourier series Expansion

\section{1. 서 론}

공간 벡터 전압 변조 방식은 다른 PWM 방식보다 직류 전압의 이용률이 크며 정상상태에서의 고조파 성 분도 억제된 스위칭 방식이다 ${ }^{[1-4]}$. 지령 전압의 크기가 SVPWM의 전압 벡터를 표시하는 육각형 내접원보다 큰 경우 인버터가 선형적으로 출력할 수 있는 범위를

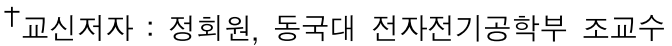

E-mail : jinwjung@dongguk.edu

"정회원, 홍익대 전자전기공학부 조교수

"정회원, $\mathrm{LG}$ 전자 $\mathrm{HA}$ 연구소 연구원

**정회원, 홍익대 전자전기공학부 교수

접수일자 : 2010. 11. 15

2차 심사 : 2011. 2. 14

1차 심사 : 2010. 12. 28

심사완료 : 2011. 2. 23
}

벗어나게 되고 전압 벡터를 육각형 영역 안으로 제한 하는 과변조 기법이 필요하다. 이러한 과변조 기법은 크게 동적과변조와 정적과변조 방식으로 나눌 수 있다 [5]. 동적 과변조 방식은 지령 전압이 육각형을 벗어날 경우 지령치 전압을 육각형의 빗면으로 사영시키는 기 법으로 전동기 벡터제어 기법 등에 적용된다. 이에 비 해 유도전동기의 $\mathrm{V} / \mathrm{F}$ 제어 기법 등에 사용되는 정적과 변조 방식은 과변조 영역에서 출력전압의 선형성을 확 장하는 것에 목적이 있으며, 전압 변조지수에 따라 선 형영역에서 구형파 구동까지 자연스럽게 천이하도록 하는 과변조 기법이다. 이 기법은 육각형 내부로 제한 된 전압이 지령전압 $\mathrm{V}^{*}$ 와 동일한 기본파 성분을 갖도 록 제어되며, 이러한 과변조기법에 대하여 많은 연구 가 이루어지고 있다 ${ }^{[6-10]}$. 지령 전압 발생을 위하여 기 
존 기법은 삼각함수의 계산에 의한 전압 크기의 결정 등을 필요로 한다. 따라서, 본 논문에서는 보다 간단하 면서도 변조지수에 따른 기본파 전압의 선형성을 유지 하는 정적과변조 기법을 제안하고자 한다.

\section{2. 기존의 정적 과변조 기법}

정적 과변조 기법은 $\mathrm{V} / \mathrm{F}$ 제어 등에서 선형제어 영역 에서 6 스텝 제어 영역 등으로 자연스럽게 천이하도록 하는 과변조 기법이다. 정적 과변조 기법은 변조지수 $\mathrm{m}$ 의 크기에 따라 영역 I, II로 나눌 수 있다 ${ }^{[5-7]}$. 변조 지수는 식 (1)과 같으며 여기서 $V_{1}^{*}$ 는 지령전압의 기 본파 첨두치이다. 6 스텝 운전의 경우 $m=1$ 이다.

$$
m=\frac{V_{1}^{*}}{\frac{2}{\pi} V_{d c}}
$$

\section{1 과변조 영역 I $(0.907 \leqq m<0.9514)$}

과변조 영역 I의 시작점은 지령치 벡터가 육각형 사 변에 접하는 시점으로 전압이 $V_{d d} / \sqrt{3}$ 의 경우이며, 이 때 변조지수 $m$ 은 0.907 이다. 그림 1 은 과변조 영역 I 에서의 기본 동작 형태를 나타낸다. 지령 전압 $V^{*}$ 의 순시 위상의 변경 없으며, 그 크기는 기본파 한주기 평균값이 지령 전압의 크기와 동일하게 되도록 출력전 압을 결정한다. 그림 1 에서와 같이 현재의 지령치 보 다 승압된 지령치 전압을 통하여, 과변조가 일어나는 즉 지령 전압이 육각형을 벗어나는 영역에서 발생하는 전압크기 저하를 그 이외에 영역에서 보상하도록 한 다. 여기서, $\alpha_{c}$ 는 승압된 지령치 전압과 빗변과의 교차 각이다.

영역 I에서는 승압이 가능한 $\mathrm{B}$ 지점 까지는 승압된 전압을 사용하고 $\mathrm{B}-\mathrm{C}$ 구간에서는 전압 지령이 육각형 빗면을 따라서 이동하도록 전압을 생성한다. 영역 I에 서의 지령 전압 벡터를 교차각과 전압지령의 위상의 관계로부터 세 구간으로 나누어 식 (2)로 나타낼 수 있다 ${ }^{[6]}$.

$$
V^{*}= \begin{cases}V_{b} e^{j \theta} & 0 \leq \theta \leq \alpha_{c} \\ \frac{V_{d c}}{\sqrt{3} \cos \left(\frac{\pi}{6}-\theta\right)} e^{j \theta} & \alpha_{c} \leq \theta \leq \frac{\pi}{3}-\alpha_{c} \\ V_{b} e^{j \theta} & \frac{\pi}{3}-\alpha_{c} \leq \theta \leq \frac{\pi}{3}\end{cases}
$$

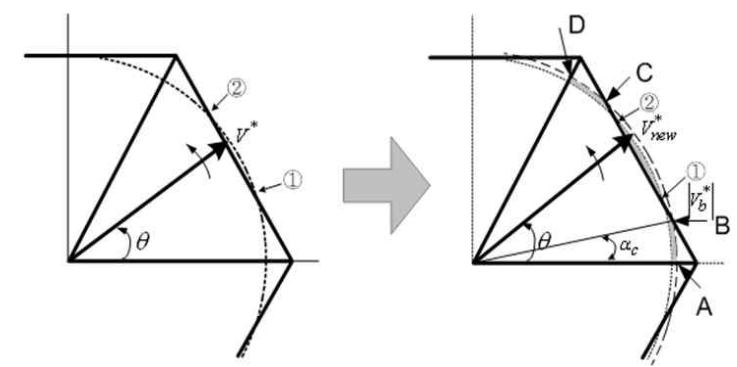

그림 1 과변조 영역 |에서의 전압 생성

Fig. 1 Reference Voltage generation in overmodulation region I

\section{2 과변조 영역 II $(0.9514 \leqq m \leqq 1)$}

영역 II는 전압 승압만으로는 원하는 전압 지령치의 크기를 생성시킬 수 없는 영역이다. 이 영역에서는 전 압 벡터의 크기와 위상 모두를 조절해야 한다. 변조 지수 $m$ 에 따라 주어진 전압 지령치의 기본파 크기를 만족하기 위해서 우측벡터 $V_{r}$ 과 좌측벡터 $V_{l}$ 에 일정 시간 머물게 함으로써 발생된 전압이 기본파 지령치 전압 크기를 만족하도록 한다. 이를 위한 영역 II에서 의 전압 지령은 식 (3)과 같다.

$$
V^{*}= \begin{cases}\frac{2}{3} V_{d c} & 0 \leq \theta \leq \alpha_{h} \\ \frac{V_{d c}}{\sqrt{3} \cos \left(\frac{\pi}{6}-\theta\right)} e^{j \theta} & \alpha_{h} \leq \theta \leq \frac{\pi}{3}-\alpha_{h} \\ \frac{2}{3} V_{d c} e^{j \frac{\pi}{3}} & \frac{\pi}{3}-\alpha_{h} \leq \theta \leq \frac{\pi}{3}\end{cases}
$$

변조지수 $m$ 에 따라 $V_{r}, V_{l}$ 벡터 즉 꼭짓점에 머무 는 시간의 조절이 필요하며 이러한 유지시간은 유지각 (holding angle) $\alpha_{h}$ 에 의해 결정된다. 유지각에 대한 전압 위상 지령은 식 (4)와 같다 ${ }^{[6]}$.

$$
\alpha_{p}=\left\{\begin{array}{cc}
0 & 0 \leq \theta \leq \alpha_{h} \\
\frac{\theta-\alpha_{h}}{\frac{\pi}{6}-\alpha_{h}} \frac{\pi}{6} & \alpha_{h} \leq \theta \leq \frac{\pi}{3}-\alpha_{h} \\
\frac{\pi}{3} & \frac{\pi}{3}-\alpha_{h} \leq \theta \leq \frac{\pi}{3}
\end{array}\right.
$$

식 (4)에서 알 수 있듯이 $V^{*}$ 의 위상 $\theta$ 가 유지각 $\alpha_{h}$ 보다 작은 영역에서는 $V_{r}$ 벡터에 머물고, $\theta$ 가 계산된 $\alpha_{h}$ 와 $\pi / 3-\alpha_{h}$ 사이 위치한 경우는 식 (4)의 중간식 형 태로 새로운 위상 지령을 생성한다. 또한 $V^{*}$ 의 위상이 $\pi / 3-\alpha_{h}$ 보다 큰 경우에는 좌측벡터 $V_{l}$ 을 출력한다. 


\section{3. 제안하는 정적 과변조 기법}

기존 방식에서 영역 $\mathrm{I}, \mathrm{II}$ 에서 변조지수 $m$ 에 따라 전 압 및 위상을 결정하게 된다. 식 (2) (4)에서 알 수 있 듯이 전압 벡터의 생성을 위해서는 삼각함수의 연산이 필요하다. 따라서 이러한 연산 절차 등을 제거하기 위 하여 과변조시 육각형의 빗변에 사영되는 전압크기는 동일위상 과변조 기법으로 결정할 수 있음을 이용하여 삼각함수 연산 없이 전압 지령치를 결정하고, 영역 II 에서의 위상 지령의 형태도 보다 간략화한 정적과변조 기법을 제안한다. 동일위상 과변조방식은 그림 2 와 같 이 육각형 외부에 존재하는 지령벡터 $\mathrm{V}^{*}$ 를 동일위상 으로 사변에 사영시키는 것으로 이때의 우측벡터와 좌 측벡터의 인가시간인 $T_{r}^{\text {New }}, T_{l}^{\text {New }}$ 는 식 (5)와 같다 ${ }^{[11]}$.

$$
T_{r}^{\text {New }}=\frac{T_{r}}{T_{r}+T_{l}} T_{s}, T_{l}^{\text {New }}=\frac{T_{l}}{T_{r}+T_{l}} T_{s}
$$

\section{1 과변조 영역 | $(0.907 \leqq m<0.9514)$}

승압되는 전압의 크기는 기본 방식과 동일하게 푸리 에 급수 전개를 통해 계산한다 ${ }^{[6,7]}$. 제안하는 방식의 전 압생성 기법을 설명하기 위하여 푸리에 급수 전개과정 을 서술하면 아래와 같다. 변조 지수 $m$ 에 따라 생성되 는 지령치 전압 벡터 $V^{*}$ 는 식 (6)과 같이 나타나며, 여기서 $V_{1}$ 은 지령전압의 기본파의 첨두치 크기이다.

$$
V^{*}=V_{1} e^{j \theta} \quad 0 \leq \theta \leq \frac{\pi}{3}
$$

등가적으로 식 (2)의 형태로 생성되는 전압의 크기가 지령 전압 기본파 크기인 $V_{1}$ 과 같도록 하는 승압된

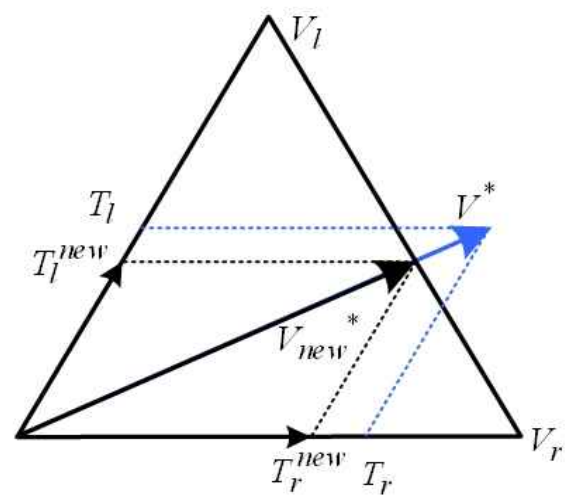

그림 2 동일위상 과변조 기법

Fig. 2 Minimum phase error PWM method
전압 크기인 $V_{b}$ 를 구하기 위한 푸리에 급수 전개는 식 (7)과 같다. 푸리에 급수의 계산시 주기에 따른 상수항 은 계산의 편리함을 위하여 소거하여 나타낸다.

$$
\begin{aligned}
\int_{0}^{\frac{\pi}{3}} V_{1} e^{j \theta} e^{-j \theta} d \theta=\int_{0}^{\alpha_{c}} V_{b} e^{j \theta} e^{-j \theta} d \theta \\
+\int_{\alpha_{c}}^{\frac{\pi}{3}-\alpha_{c}} \frac{V_{d c}}{\sqrt{3} \cos \left(\frac{\pi}{6}-\theta\right)} e^{j \theta} e^{-j \theta} d \theta \\
+\int_{\frac{\pi}{3}-\alpha_{c}}^{\frac{\pi}{3}} V_{b} e^{j \theta} e^{-j \theta} d \theta
\end{aligned}
$$

$\int \frac{1}{\cos \xi} d \xi=\ln \tan \left(\frac{\pi}{4}+\frac{\xi}{2}\right)$ 임을 이용하여, 식 (7)을 정리하면 식 (8)을 얻는다.

$$
V_{1} \times \frac{\pi}{3}=V_{b} \times 2 \alpha_{c}-\frac{V_{d c}}{\sqrt{3}} \int_{\frac{\pi}{6}-\alpha_{c}}^{-\frac{\pi}{6}+\alpha_{c}} \frac{1}{\cos \xi} d \xi
$$

여기서 $\frac{\pi}{6}-\theta=\xi$ 로 하여 식 (8)을 정리하면 아래의 식 (9), (10)이 얻어진다.

$$
\begin{aligned}
V_{1}= & \frac{6}{\pi} \alpha_{c} V_{b} \\
& +\frac{\sqrt{3}}{\pi} V_{d c}\left[\ln \tan \left(\frac{\pi}{3}-\frac{\alpha_{c}}{2}\right)-\ln \tan \left(\frac{\pi}{6}-\frac{\alpha_{c}}{2}\right)\right] \\
V_{b}= & \frac{V_{d c}}{\sqrt{3}} \frac{1}{\cos \left(\frac{\pi}{6}-\alpha_{c}\right)}
\end{aligned}
$$

여기서, 식 (10)을 식 (9)에 대입 정리하면 그림 1에 서 $\mathrm{B}$ 점에 해당하는 교차각 $\alpha_{c}$ 와 변조 지수 $m$ (등가적 으로 $\left.V_{I}\right)$ 의 관계를 식 (11)과 같이 얻을 수 있다.

$$
\begin{aligned}
V_{1}= & \frac{6}{\pi} \times \alpha_{c} \times \frac{V_{d c}}{\sqrt{3}} \times \frac{1}{\cos \left(\frac{\pi}{6}-\alpha_{c}\right)} \\
& +\frac{\sqrt{3}}{\pi} \times V_{d c}\left[\ln \tan \left(\frac{\pi}{3}-\frac{\alpha_{c}}{2}\right)-\ln \tan \left(\frac{\pi}{6}-\frac{\alpha_{c}}{2}\right)\right]
\end{aligned}
$$

변조 지수 $m\left(V_{1}\right)$ 으로부터 식 (11)을 이용하여 $\alpha_{c}$ 를 구하고, 구해진 $\alpha_{c}$ 를 식 (10)에 대입하면 $V_{b}$ 의 크 기를 구할 수 있다. 우선 새로운 변조 지수 $m_{v 2}$ 를 식 (12)와 같이 본 논문에서 정의한다. 식 (13)은 식 (12) 
와 비교하기 위해 변조 지수 $m$ 을 다시 나타낸 것이며, 원 지령치 전압 크기이므로 $m_{V 1}$ 라고 명하였다. 식 (12) 와 같이 변조지수를 순시치로 다시 나타낸 것은 실제 구현에 있어서 전압 지령치는 순시치 크기를 갖기 때 문이다. 식 (12)의 $V_{i n s t}^{*}$ 는 지령 전압의 순시치이므로 식 (13)의 $V_{1}^{*}$ 즉 기본파 크기의 첨두치와 구별된다.

$$
\begin{aligned}
& m_{v 2}=\frac{V_{i n s t}^{*}}{(2 / \pi) V_{d c}} \\
& m=\frac{V_{1}^{*}}{(2 / \pi) V_{d c}} \Rightarrow m_{v 1}
\end{aligned}
$$

한편, 과변조 영역 시작 지점의 $V_{1}$ 의 크기는 $V_{d c} d \sqrt{3}$ 이고 이때 변조 지수 $m$ 은 0.907 이다. 선형영역 에서는 지령치의 기본파와 출력의 기본파크기가 동일 하므로 $m_{v 2}$ 또한 0.907 이다. 영역 I의 끝은 교차가 $\alpha_{c}$ 가 $0^{0}$ 인 경우로 식 (11)과 식(10)로부터 이 경우 $V_{1}$ 은 $0.6057 V_{d c}$ 이며, $V_{b}=0.667 V_{d c}$, 이에 대응하는 $m_{V I}$ 은 $0.9514, m_{v 2}$ 는 1.0472임을 알 수 있다. $m_{v 2}=1.0472$ 인 경우는 식 (12)에 서 알 수 있듯이 $V_{b}$ 가 육각형에 외 접하는 전압크기인 $2 / 3 V_{d c}$ 인 경우다. 식 (1), (10), (11) 을 사용하여 변조지수 $m$ (등가적으로 $m_{v 1}$ )에 따른 $m_{v 2}$ 를 도시하면 그림 3 과 같다. 매트랩의 curve fitting tool을 사용하여 세 구간으로 나누어 근사화하 면 표 1 과 같이 정리할 수 있다. 실제 PWM 구현 시 에는 표 1 의 근사식을 사용한다. 한편, 그림 3 에서 볼 수 있듯이 $m_{V 1}$ 은 0.907-0.9514, $\mathrm{m}_{\mathrm{v} 2}$ 는 0.907-1.0472의 범위를 갖는다.

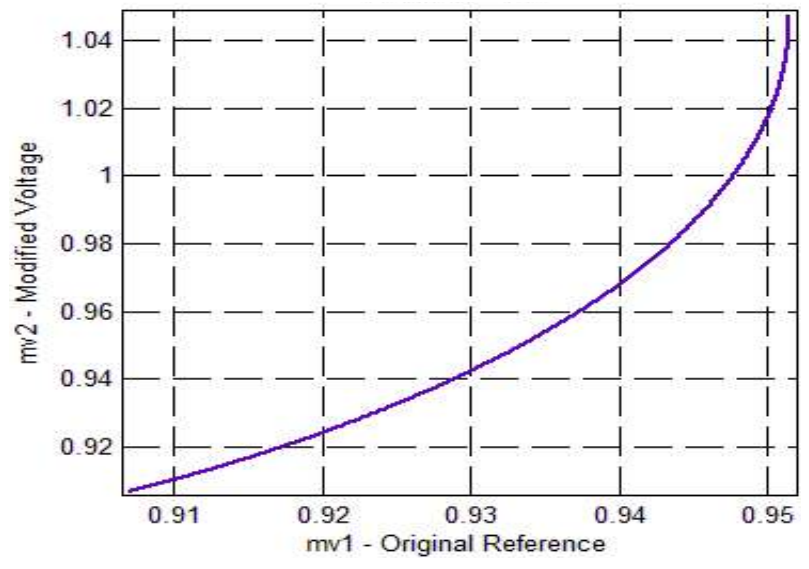

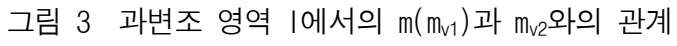

Fig. 3 Relationship between $\mathrm{m}_{\left(\mathrm{m}_{\mathrm{v}}\right)}$ and $\mathrm{m}_{\mathrm{v} 2}$ in the overmodulation region I
표 1 과변조 영역 I에서의 변조지수 근사식

Table 1 Approximated boosted vol tage corresponding to the modulation index in the overmodulation region I

\begin{tabular}{c|c}
\hline \hline \multicolumn{2}{c}{ 과변조 영역 I $(0.9069 \leqq m<0.9514)$} \\
\hline \hline$m$ 의 범위 & $m_{v 2}$ 의 근사식 \\
\hline $0.9069 \leqq m<0.94$ & $m_{v 2}=1.731 \times m-0.6656$ \\
\hline $0.94 \leqq m<0.951$ & $m_{v 2}=5.48 \times m-4.19$ \\
\hline $0.951 \leqq m \leqq 0.9514$ & $m_{v 2}=35.82 \times m-33.04$ \\
\hline \hline
\end{tabular}

그림 4는 제안하는 방식의 영역 I에서의 전압 생성 개념도이다. 변조 지수에 따른 표 1 을 이용하여 $m_{\mathrm{V} 2}$ 즉 $V_{b}$ 크기를 갖는 새로운 전압을 생성하고, 이 전압 지령 $V_{b} e^{j \theta}$ 는 그림 4 의 점선과 같이 위상에 따라 회전 하게 된다. 전압의 위상이 교차각인 $\alpha_{c}$ 가 되었을 때 즉 $\mathrm{B}$ 점의 위치에서 $T_{r}+T_{l}=T_{S}$ 가 된다. $\mathrm{B}-\mathrm{C}$ 영역에 서는 $V_{b} e^{j \theta}$ 가 육각형의 외부에 존재하므로 $T_{r}+T_{1}>$ $T_{S}$ 가 될 것임을 알 수 있다. 구간 $\mathrm{B}-\mathrm{C}$ 에 있음의 판별 은 $T_{r}+T_{I}>T_{S}$ 인 조건에 의해 구간 결정이 자연스 럽게 결정되고, 육각형 빗면으로 사영되는 전압벡터는 동일위상 과변조 기법을 나타내는 식 (5)를 통해 결정 하면 된다. 따라서, $V_{b}$ 로 승압된 전압 벡터 $V_{b} e^{j \theta}$ 를 이 용하여 $T_{r}$ 과 $T_{l}$ 을 계산하고, $T_{r}+T_{l}>T_{s}$ 인 경우 식 (5)에 의해 인가시간을 결정하면 간단히 정적 과변조 를 구현할 수 있다. 그림 4에서 알 수 있듯이 본 기법 에서는 $m$ 에 대한 승압된 전압 지령을 표 1 을 통해 구 함을 알 수 있다.

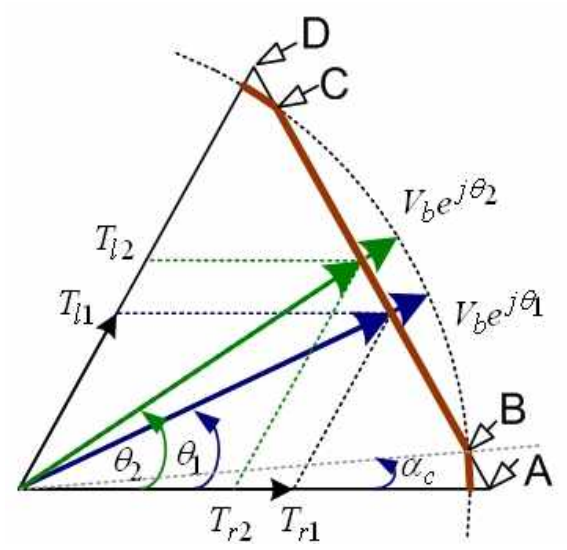

그림 4 영역 |에서의 전압생성

Fig. 4 Voltage generation in the overmodulation region I 
이에 비해 기존 정적 과변조 방식에는 표 1 로 나타나 는 근사식은 $m$ 과 교차각 $\alpha_{c}$ 의 관계를 구한다 ${ }^{[6,7]}$. 즉 기존 방식에서는 $m$ 에 대응하는 $\alpha_{c}$ 를 구하고 식 (2)와 같이 전압 위상 $\theta$ 가 포함된 삼각함수 연산을 통해 전 압 지령치를 발생하는 단계를 거치게 된다. 이에 비해 제안하는 방식은 변조지수 $m$ 에 따라 순시치 전압 지 령 $\left(V_{b}\right.$, 등가적으로 $\left.m_{v 2}\right)$ 을 표 1 의 근사식을 통해 결정 하게 되고, $T_{r}+T_{l}>T_{s}$ 의 조건이 발생시 동일위상 과 변조 방식에 의해 스위칭 시간만을 조정하는 간단한 정적과변조 기법이다.

\section{2 과변조 영역 II $(0.9514 \leqq m \leqq 1)$}

$m_{v 2}$ 가 1.0472 인 즉 승압된 전압의 크기가 $2 / 3 V_{d c}$ 가 되는 시점 이후로는 더 이상 출력 전압을 증가할 수 없 으므로 영역 II로 모드가 전환이 필요하다. 본 제안기법 에서는 영역 I에서와 마찬가지로, 영역 II에서도 동일위 상 과변조 기법을 사용하여 새로운 전압 지령을 생성한 다. 영역 II에서는 전압 생성 개념도는 그림 5 와 같다.

즉 지령치 전압은 $2 / 3 V_{d c} e^{j \theta}$ 의 형태이다. 전압의 크 기는 $2 / 3 V_{d c}$ 로 고정하고 변조지수에 따라 계산된 유지 각에 따라 위상 지령만을 변경하게 된다. 새로운 위상 각 지령치 식 (4)를 더욱 간략화 하기 위해 식 (14)와 같이 생성한다. 위상 지령 형태는 기존 방식과 유사하 다. 지령 전압의 위상이 유지각 보다 작은 $\mathrm{A}-\mathrm{B}$ 구간에 서는 $\mathrm{A}$ 지점에 머물게 하고, $\mathrm{B}-\mathrm{C}$ 지점에서는 $2 / 3 V_{d c} e^{j \theta}$ 의 전압 지령을 가지며 위상각이 $\pi / 3-\alpha_{h}$ 인 경우인 $\mathrm{C}-\mathrm{D}$ 구간에서는 $\mathrm{D}$ 지점의 전압인 $2 / 3 V_{d c} e^{j \frac{\pi}{3}}$ 를 출력한다.

$$
\theta^{*}=\left\{\begin{array}{cl}
0 & 0 \leq \theta \leq \alpha_{h} \\
\theta & \alpha_{h} \leq \theta \leq \frac{\pi}{3}-\alpha_{h} \\
\frac{\pi}{3} & \frac{\pi}{3}-\alpha_{h} \leq \theta \leq \frac{\pi}{3}
\end{array}\right.
$$

변조지수 $m$ 즉 등가적인 값인 $V_{1}$ 의 크기에 따른 유 지각 계산은 다음과 같다. 우선 유지각의 계산은 영역 I과 동일한 방법으로 식 (3)을 사용하여 푸리에 급수 전개하면 식 (15)를 얻을 수 있다.

$$
\begin{aligned}
\int_{0}^{\frac{\pi}{3}} V_{1} d \theta=\int_{0}^{\alpha_{h}} & \frac{2}{3} V_{d c} e^{-j \theta} d \theta+\int_{\alpha_{h}}^{\frac{\pi}{3}-\alpha_{h}} \frac{V_{d c}}{\sqrt{3} \cos \left(\frac{\pi}{6}-\theta\right)} d \theta \\
& +\int_{\frac{\pi}{3}-\alpha_{h}}^{\frac{\pi}{3}} \frac{2}{3} V_{d c} e^{j\left(\frac{\pi}{3}-\theta\right)} d \theta
\end{aligned}
$$

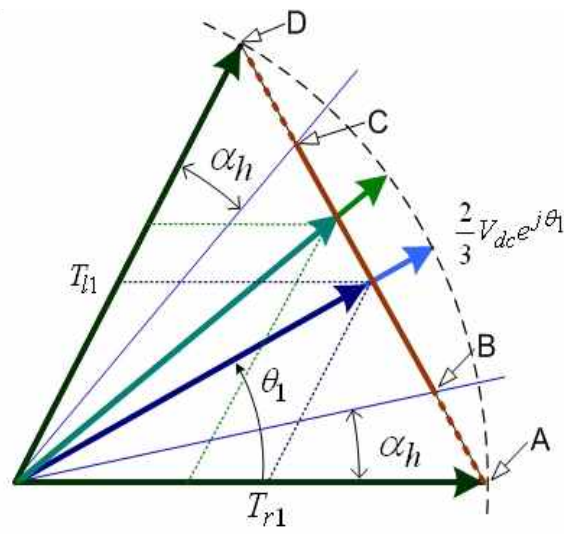

그림 5 과변조 영역 ||에서의 전압벡터의 생성

Fig. 5 Reference voltage vector generation in the overmodulation region II

표 2 과변조 영역 ||에서의 유지각의 근사식

Table 2 Approximated holding angle corresponding to the modulation index in the overmodulation region 11

\begin{tabular}{c|c}
\hline \hline \multicolumn{2}{c}{ 과변조 영역 II $(0.9514 \leqq m \leqq 1)$} \\
\hline \hline$m$ 의 범위 & 유지각 $\alpha_{h}$ 의 근사식 \\
\hline $0.9514 \leqq m<0.955$ & $\alpha_{h}=20.73 \times m-19.71$ \\
\hline $0.955 \leqq m<0.995$ & $\alpha_{h}=7.797 \times m-7.35$ \\
\hline $0.995 \leqq m<1$ & $\alpha_{h}=19.87 \times m-19.37$ \\
\hline$m=1$ & $\alpha_{h}=\pi / 6$ \\
\hline \hline
\end{tabular}

식 (15)은 식 (16)과 같이 전개되며, 이를 실수부와 허수부로 나누어 정리하면 식 (17)을 얻을 수 있다.

$$
\begin{aligned}
V_{1} \cdot \frac{\pi}{3}= & \frac{2}{3} V_{d c} \cdot j\left[e^{-j \alpha_{h}}-1\right]+\frac{V_{d c}}{\sqrt{3}} \cdot \int_{\alpha_{h}}^{\frac{\pi}{3}-\alpha_{h}} \frac{V_{d c}}{\cos \left(\frac{\pi}{6}-\theta\right)} d \theta \\
& +\frac{2}{3} V_{d c} \cdot j\left[1-e^{-j \alpha_{h}}\right] \\
V_{1}= & \frac{4}{\pi} V_{d c} \sin \alpha_{h} \\
+ & \frac{\sqrt{3}}{\pi} V_{d c}\left[\ln \tan \left(\frac{\pi}{3}-\frac{\alpha_{h}}{2}\right)-\ln \tan \left(\frac{\pi}{6}-\frac{\alpha_{h}}{6}\right)\right]
\end{aligned}
$$

여기서, 식 (1)의 변조지수 $m$ 을 이용하여 식 (17)을 정리하면 변조지수 $m$ 과 $\alpha_{h}$ 와의 관계인 식 (18)을 얻 을 수 있다. 


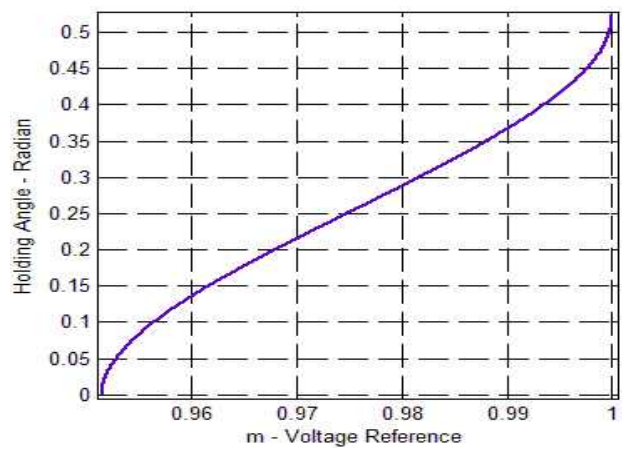

그림 6 과변조 영역 ||에서의 $m$ 과 유지각과의 관계

Fig. 6 Relation between $\mathrm{m}$ and holding angle in the overmodulation region $\mathrm{II}$

$m=2 \sin \alpha_{h}+\frac{\sqrt{3}}{2}\left[\ln \tan \left(\frac{\pi}{3}-\frac{\alpha_{h}}{2}\right)-\ln \tan \left(\frac{\pi}{6}-\frac{\alpha_{h}}{6}\right)\right]$

변조지수와 유지각 $\alpha_{h}$ 의 관계는 그림 6 과 같다. 영역 $\mathrm{I}$ 에서와 마찬가지로 세 구간으로 나누어, 1 차 선형 방정 식으로 근사화시키면 표 2와 같이 나타낼 수 있다.

과변조 영역 II에서는 변조지수 $m$ 에 따른 유지각 $\left(\alpha_{h}\right)$ 의 크기는 표 2에 나타난 근사식을 통해 결정하 며, 이를 이용하여 전압 위상 지령은 식 (14)에 의해 결정된다. $m_{V 1}$ 에 해당하는 지령치 전압의 순시치 크기 는 $2 / 3 V_{d c}$ (등가적으로 $m_{v 2}=1.0472$ )로 고정된다. 그림 5 에서 보였듯이 영역 II에서는 지령 전압 벡터가 항상 육각형의 사변을 벗어나는 경우이므로 지령치 전압에 대한 스위칭 시간은 동일위상 과변조 기법인 식 (5)를 통해서 사변에 사영시켜 구한다. 그림 7 은 제안한 정 적 과변조 기법에 대한 흐름도이다. 영역 I에는 표 1 의 순시치 전압 크기와 영역 II에서는 유지각 크기를 계 산하게 되고, 영역 I에서 위상 지령의 변동은 없고 영 역 II에서는 식 (14)의 위상 지령을 취한다. $T_{r}+T_{l}>$ $T_{S}$ 인 경우에는 식 (5)를 적용한다.

\section{4. 실험 결과}

실험은 5 마력 유도전동기, 게이트 드라이버는 Dual IGBT구동 및 자체적으로 절연된 전압 및 데드타임을 갖는 세미크론사의 SKHI22A를 사용하였다. PWM 인 터럽트 루틴에서는 지령치 전압의 크기에 따라 선형영 여과 과변조영역 I, II로 구분하여 전압과 각도를 지령 하게 된다. 그림 8은 실험에서 지령속도에 따른 상전 류 및 선간 전압, 스위칭 인가 시간 파형을 보여 주고

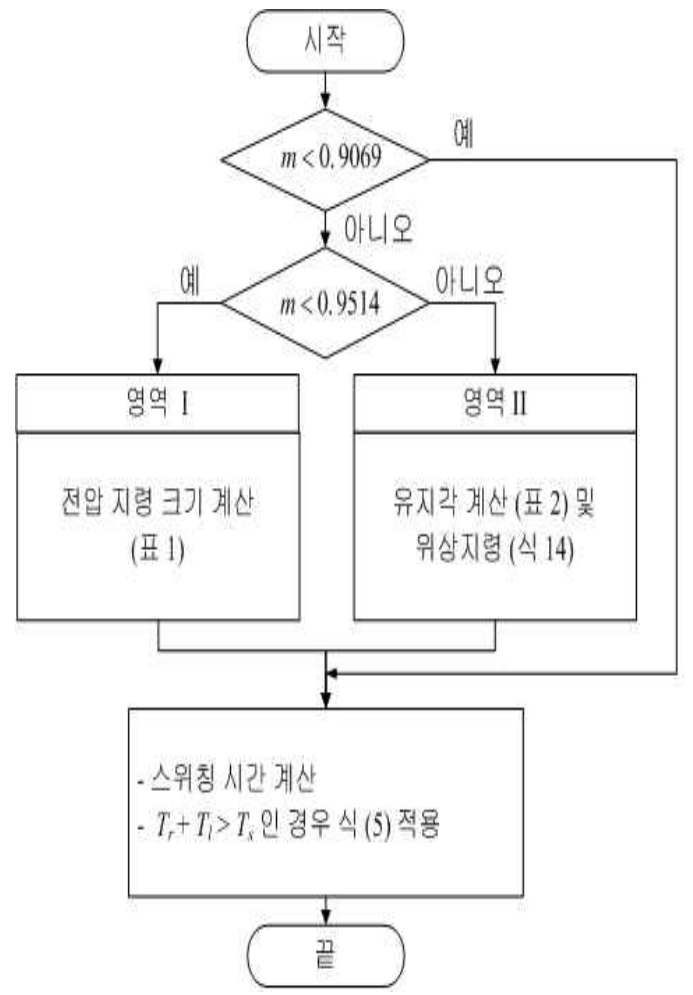

그림 7 과변조 영역에서 지령 전압 생성 흐름도

Fig. 7 Flowchart for generating reference vol tage in overmodulation regions

있다. 그림 $8(\mathrm{a})$ 는 전동기 속도가 500rpm일 때는 선형 영역에 해당된다. 선형 영역에서 상전류는 전류의 왜 곡이 없이 정현파 전류를 나타내고 있다.

스위칭 타임은 $\mathrm{D} / \mathrm{A}$ 로 한상만 출력하였다. 그림 8(b) 는 속도가 $1600 \mathrm{rpm}$ 인 경우로 과변조 영역 I에 해당된 다. 과변조의 영향에 따라 스위칭이 존재하는 구간이 있음을 알 수 있으며, 스위칭 타임 파형 또한 시뮬레 이션 파형과 같음을 볼 수 있다. 그림 8(c)는 전동기 속도가 $1700 \mathrm{rpm}$ 인 경우로 과변조 영역 III에 해당된다. 전류의 파형이 과변조 영역 I에 비해 더욱 전류의 왜 곡이 나타낸다. 스위칭 타임 파형은 사다리꼴 모양으 로 시뮬레이션처럼 출력이 되고 있다. 그림 $8(\mathrm{~d})$ 는 전 동기 속도가 1750rpm일 때로 6 스텝 운전에 해당된다. 전류파형은 고조파의 영향으로 전류의 왜곡이 나타남 을 볼 수 있다. 또한 선간 전압 파형이 6 스텝 구동과 같이 전압 벡터 전환 시에 스위칭이 일어나지 않는 구 형파 구동의 전형적인 형태로 나타남을 볼 수 있으며, 스위칭 타임 파형은 사각파 형태로 출력됨을 볼 수 있 다. 


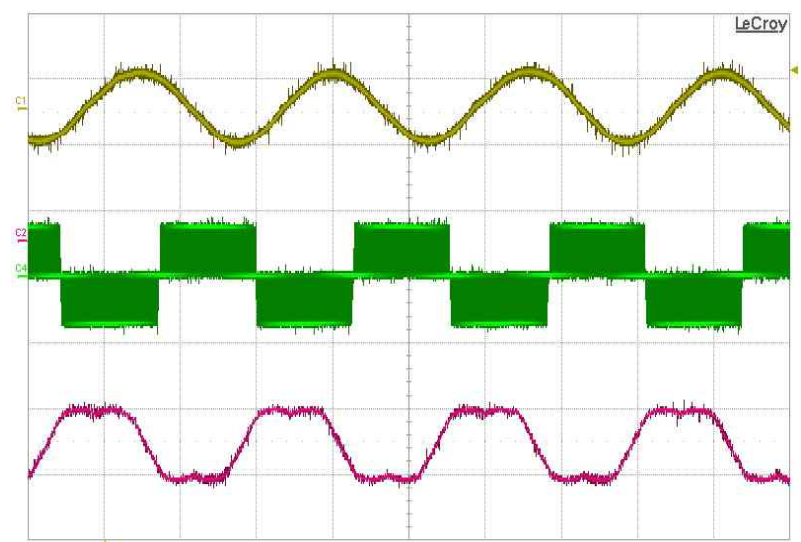

(a) $500 \mathrm{rpm}$, 선형영역

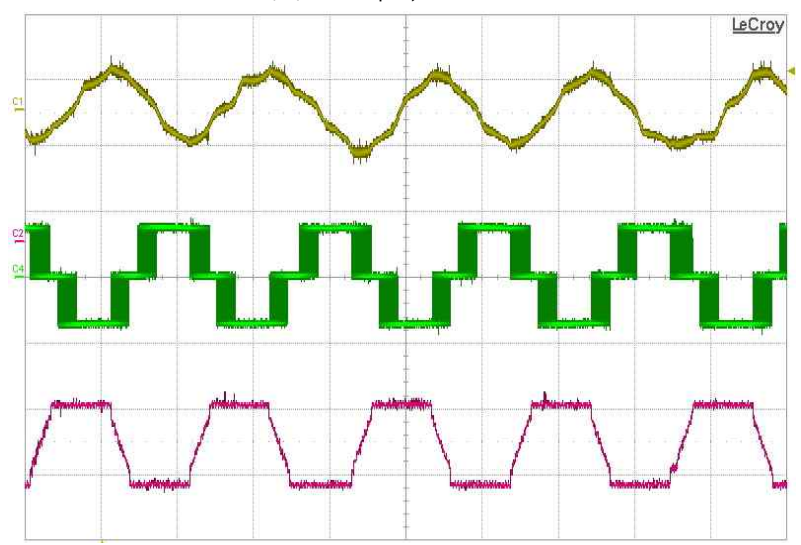

(c) $1700 \mathrm{rpm}$, 과변조 영역 II

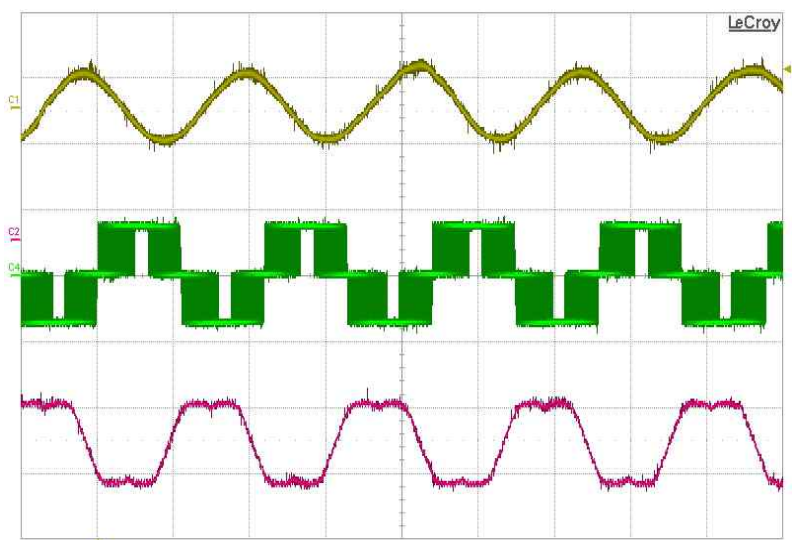

(b) $1600 \mathrm{rpm}$, 과변조 영역 ।

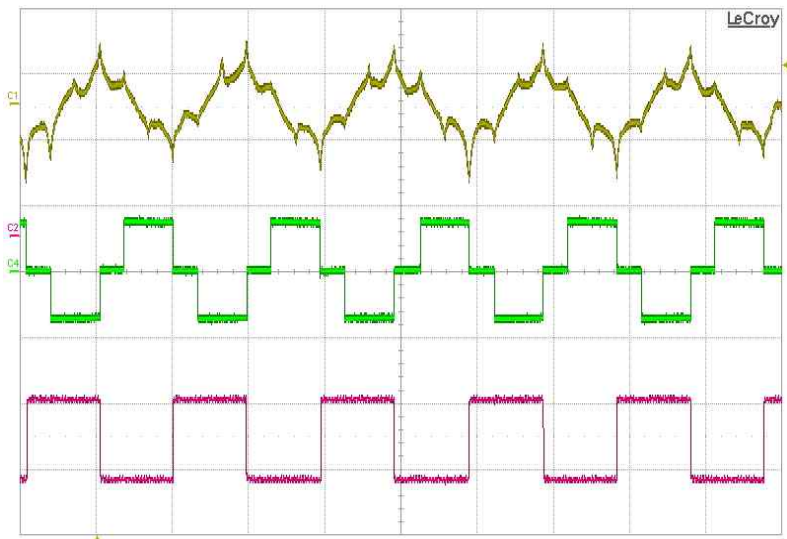

(d) 1750rpm, 과변조 영역 II, 6 스텝 운전

그림 8 실험 파형 (각 그림 위로부터 상전류 [5A/div], 선간전압 [350V/div], 스위칭 인가시간)

Fig. 8 Experimental waveform (From the top - I ine current [5A/div], I ine to I ine voltage [350V/div], switching time)

\section{5. 결 론}

본 논문에서는 유도전동기의 $\mathrm{V} / \mathrm{F}$ 제어와 같은 정적 과변조 기법 시 과변조 전압의 생성 및 지령치 전압의 출력 선형성을 증대하기 위한 정적 과변조에 대한 것 이다. 제안한 과변조기법은 변조지수에 따라 영역 I에 서는 승압된 전압의 크기를 구하는 방식 크기만을 택 하여 전압크기만을 영역 II에서는 유지각만을 스위칭 시간 계산에 사용하게 되어 구현이 간단한 과변조 기 법이다. 제안한 기법의 타당성을 실험을 통하여 검증하 였다.

이 논문은 2010년도 정부(교육과학기술부)의 재원 으로 한국연구재단의 기초연구사업 지원을 받아 수 행된 것임 (2010-0008884)

\section{참 고 문 헌}

[1] H.W. Van der Broeck, H.C. Skudelny, and G.V. Stanke, "Analysis and Realization of a Pulse Width Modulator Based on Voltage Space Vectors", IEEE Trans. on Industry Applications, Vol. 24, No. 1, pp. 142-150, 1988, Jan./Feb.

[2] S. Fukuda, H. Hasegawa, and Y. Iwaji, "PWM Technique for Inverter with Sinusoidal Output Current", IEEE Trans. on Power Electronics, Vol. 5, No. 1, pp. 54-61, 1990, Jan.

[3] 한대웅, 김상훈, "폴전압을 이용한 SVPWM 인버터의 과 변조 기법”, 전력전자학회 논문지, 제7권, 제2호, $\mathrm{pp}$. 149-157, 2002.

[4] J.O.P. Pinto, B.K. Bose, L.E.B. DaSilva, and M.P. Kazmierkowski, "A Neural Network Based Space Vector PWM Controller for Voltage-fed Inverter 
Induction Motor Drive", IEEE Trans. on Industry Applications, Vol. 36, No. 6, pp. 1628-1636, 2000, Nov./Dec.

[5] 김상훈, $\mathrm{DC}$ 및 $\mathrm{AC}$ 모터제어, 북두출판사, 2007.

[6] 배장호, 김연충, 원충연, 최종묵, 기상우, 배기훈, "공간벡 터 PWM의 과변조 영역에서 출력전압 선형화", 전자공 학회논문지, 제36권, 제11호, pp. 1374-1385, 1999.

[7] D.C. Lee, and G.M Lee, "A Novel Overmodulation Technique for Space-Vector PWM Inverters", IEEE Trans. on Power Electronics, Vol 13, No. 6, pp. 1144 $-1151,1998$, Nov.

[8] T.A. Bernardes, H. Pinheiro, and V.F. Montagner, "Current control system to PMSG in overmodulation region", Brazilian Power Electronics Conference, pp. 1219-1226, 2009, Oct.

[9] L.C. Tan, Y.H. Li, and P. Wang, "An Overmodulation Method for Space Vector PWM Current Source Inverters", IEEE Conference on Industrial Electronics and Applications, pp. 2431-2434, 2007, May.

[10] K. Sun. Q. Wei, L. Huang, and K. Matsuse, "An Overmodulation Method for PWM-Inverter-Fed IPMSM Drive With Single Current Sensor", IEEE Trans. on Industrial Electronics, Vol. 57, No. 10, pp. 3359-3404, 2010, Oct.

[11]T.G. Habetler, "A Space Vector-based Rectifier Regulator for ac/dc/ac Converters", in Proc. EPE, Vol. 2, pp. 101-107, 1991.

\section{저 자 소 개}

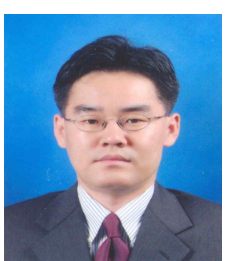

이동명 (李東明)

1969년 8월 25일생. 1994년 한양대 전기공 학과 졸업. 1996년 동 대학원 전기공학과 졸업(석사). 2004년 조지아공대 ECE 졸업 (공박). 1996년 2000년 LG전자 DA연구소 주임연구원. 2004년 2006년 삼성SDI 중앙 연구소 책임연구원. 2007년 한양대 BK21 연구교수. 2008년 현재 홍익대 전자전기공학부 조교수. 당 학회 국문지 편집위원.

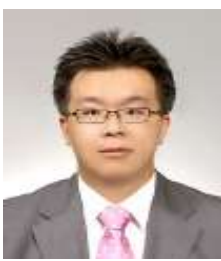

\section{김진 호 $($ 金填鎬 $)$}

1981년 7월 8일생. 2008년 홍익대 공대 전 기전자공학부 졸업. 2011년 동 대학원 전 자정보통신공학과 졸업(석사). 2011년 현재 LG전자 HA연구소 연구원.

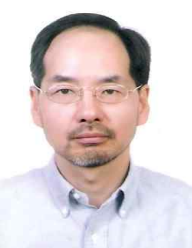

\section{양현 석 (梁玄錫)}

1961년 4월 7일생. 1984년 Purdue University 전기공학과 졸업. 1991년 University of California, Berkeley 졸업(공박). 1992년 현 재 홍익대 전자전기공학부 교수.

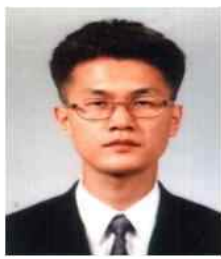

\section{정 진 우 (鄭鎭佑)}

1969년 1월 11일생. 1991년 2월 한양대 전 기공학과 졸업. 1997년 2월 동 대학원 전 기공학과 졸업(석사). 2005년 6월 The Ohio State Univ. 전기공학과 졸업(공박). 1997년 2000년 LG전자 Digital Appliance 연구소. 2005년 2008년 삼성SDI 중앙연구소 책임연구원. 2008년 현 재 동국대 전자전기공학부 조교수. 당 학회 국문지 편집위원. 